\title{
硼酸蒸気によるマグネシア棟瓦の侵蝕過程
}

\author{
大河原晋 - 山口明良 \\ (名古屋工業大学, 篣業工学科)
}

\section{The Corrosion Process of Magnesia Brick by the Vapour of Boric Oxide}

\author{
By \\ Susumu ŌKAWARA and Akira YAMAGUCHI \\ (Nagoya Institute of Technology)
}

\begin{abstract}
One of the important properties of the checker bricks is the resistance to attack of the variours vapour of batch materials and the melting glass at high temprature in the tank.

In this paper, the corrosion process of magnesia brick under influence of the vapour of boric oxide is studied by changing the temperature and the time of corrosion by its vapour.

At the temperature of $1300^{\circ} \mathrm{C}$, magnesium-orthoborate $\left(3 \mathrm{MgO} \cdot \mathrm{B}_{2} \mathrm{O}_{3}\right)$ was formed in all portion of the brick, but after about 20 hours in this reaction process, liquid phase of composition of magnesium-metaborate $\left(\mathrm{MgO} \cdot \mathrm{B}_{2} \mathrm{O}_{3}\right)$ was formed at the surface of the brick.

$\mathrm{But}$, at the temperature of $1400^{\circ} \mathrm{C}$, only magnesium-orthoborate $\left(3 \mathrm{MgO} \cdot \mathrm{B}_{2} \mathrm{O}_{3}\right)$ was formed through all reaction process. It is supposed that as the reaction product $\left(3 \mathrm{MgO} \cdot \mathrm{B}_{2} \mathrm{O}_{3}\right)$ in the first rcaction process was formed in liquid phase directly this product had no chance to change into the next reaction product $\left(\mathrm{MgO} \cdot \mathrm{B}_{2} \mathrm{O}_{3}\right)$.

[Received June 23, 1967]
\end{abstract}

\section{1. 緒言}

ガラスタンク窯等の蓄熱煉瓦, あるいは天井煉瓦は, 操業温度の上昇等によって, 廃ガスやガラ゙ス成分から発 生する種々の蒸気による侵蝕がかなり大きいものとなっ ている．著者らは，これら各種蒸気による各種煉瓦の侵 蝕機構を解明するために一連の研究を行なっているが, ここではその研究の一部であるマグネシア煉瓦の硼酸蒸 気による侵蝕機構について研究した結果を報告する.

\section{2. 実 験 方 法}

\section{1 硼 酸蒸気}

キシダ化学製, $\mathrm{H}_{3} \mathrm{BO}_{3}$ 特級試薬を $10 \mathrm{cc}$ 白金坩堝に 入れ，ブンゼンバーナーで加熱して完全に透明なガラス 状態となるまで熔融したものを, 嗍酸蒸気発生源として 用いた。

\section{2 試料}

市販マグネシア焼成煉瓦をダイヤモンドカッターで一 辺 $16 \mathrm{~mm}$ の立方体に切り出した. この煉瓦の化学組成 は $90 \% \mathrm{MgO}, 6 \% \mathrm{SiO}_{2}, 1.5 \% \mathrm{Fe}_{2} \mathrm{O}_{3}, 3 \% \mathrm{CaO}$ であ り，X線解析及び鏡検結果によれば（図-1）10７0 わたる大小のペリクレース粘子が，ほぼ $600 \sim 2,000 \mu$ にわたる粒塊部分（図-1-G 部分）と粒塊の間を充填し ている結合部分 (図-1-S 部分) とを構成しており，こ れらが煉瓦組織の大半を占め，他にペリクレース粒子間 に他形をなした少量のフォルステライト結晶が散在して

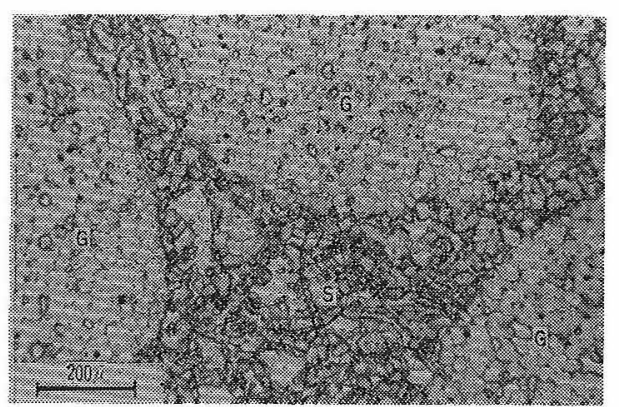

$$
\begin{aligned}
& \mathrm{G} \text { : magnesia clinker grain } \\
& \mathrm{S} \text { : bonding part }
\end{aligned}
$$

Fig. 1. The microscopic texture of the magnesia brick.

いた。な执この試料の見掛気孔率は $16 \%$ であった。

またこの試料の他に関東化学製，水酸化マグネシア特 級試薬を径 $15 \mathrm{~mm}$ ，厚さ $10 \mathrm{~mm}$ の円柱状に加圧成形 し， $1400^{\circ} \mathrm{C} ， 5$ 時間炍焼したペレットについても実験安 行なった.

\section{3 実験装置}

試料周辺に括ける硼酸の蒸気圧を常に一定に保ち，硼 酸蒸気の流動や外部一の洩れを出来るだけ生じないよう に密閉した装置をせットした（図-2）。そして $1300^{\circ} \mathrm{C}$ および $1400^{\circ} \mathrm{C}$ の各一定温度になった電気炉（岸化珠素 発熱体）の中にこのセットをそのまま雨入して，一定時 間を経過した後に炬からこのセットを取り出して空冷し 


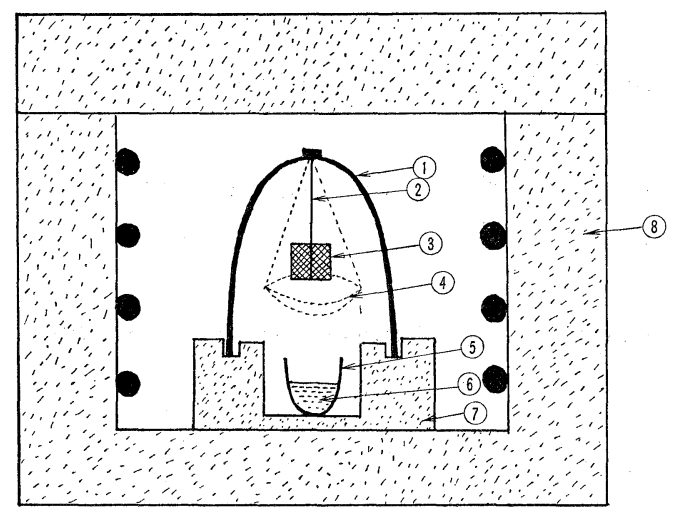

(1) Alumina crucible (2) Pt-wire (3) Sample (4) Platinum saucer (5) Platinum crucible (6) Boric oxide (melted) (7) Refractory (8) Electric furnace

Fig. 2. The apparatus of experiment for treating MgO-brick with vapour of boric oxide.

た．なお長時間にわたる実験では，棟瓦と硼酸の反応物 （液相）が滴下する場合もあったので，必要に応じて試 料下方の適当な位置に径 $20 \mathrm{~mm}$ の白金血を取り付けた (図-2, 点線位置).

また，蒸気侵蝕の温度による影響をみるために，適当 な温度勾配をむつ電気炉（図-3）を作製して別の実験を 行なった．この炉内には，アルミナ燃焼管が挿入してあ り，管内には上部にいくにしたがって低温となるような

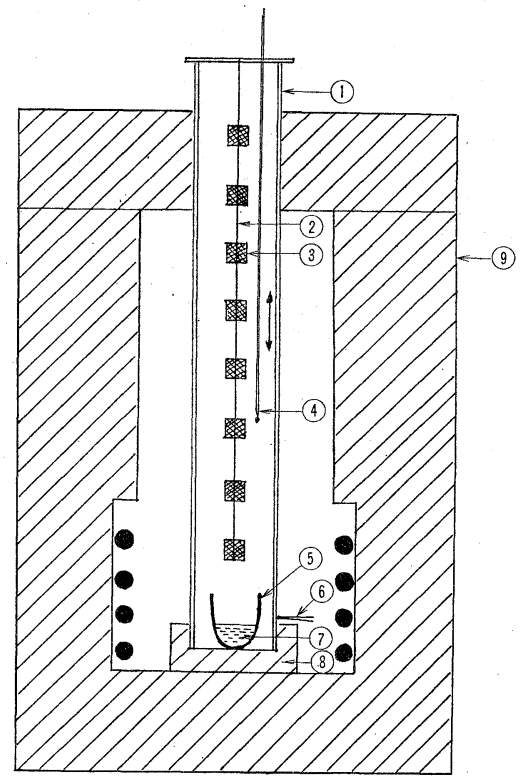

(1) Alumina tube (2) Pt-wire (3) Sample (4) T.C for mesurement of temperature gradient in $\mathrm{Al}_{2} \mathrm{O}_{3}$-tube (5) Platinum crucible (6) Fixed thermocouple in the furnace (7) Boric oxide (melted) (8) Refractory (9) Electric furnace

Fig. 3. The apparatus for treating MgO-brick with vapour of boric oxide at various temperature.
緩やかな温度勾配がつけてあり，この中へ一辺 $10 \mathrm{~mm}$ の立方体に切り出した上記のマグネシア煉瓦 8 個を白金 線で垂直に連結して一定時閒吊した。 その際，蒸発物付 近の温度を常時 $1400^{\circ} \mathrm{C}$ 亿保ち，各試料の位置する場所 の温度はそれぞれの試料付近までこの炉の上方から熱電 対を挿入して測定した。

\section{3. 実 験 結 果}

\section{$3.1 \mathrm{X}$ 線回折結果}

3.1.1 $1300^{\circ} \mathrm{C}$ の温度段階における実験結果 硼酸 蒸気中で煉瓦試料を保持すると，20 時間以上 経過した ものには，冷却した際に試料表面に明らかに異質層とみ なし得る剝離層を生成する.この生成した剝離層を取除 いた試料内部，それに剝離層の生成しない20 時間以内 の試料では試料全体にわたって新しく $3 \mathrm{MgO} \cdot \mathrm{B}_{2} \mathrm{O}_{3}$ 結
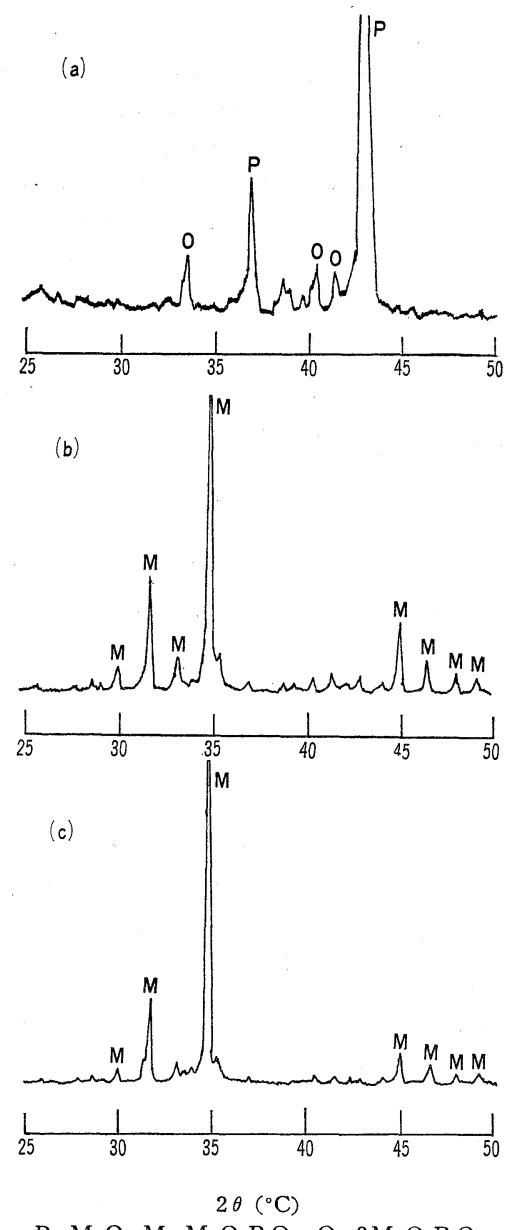

$\mathrm{P}: \mathrm{MgO} \quad \mathrm{M}: \mathrm{MgO} \cdot \mathrm{B}_{2} \mathrm{O}_{3} \quad \mathrm{O}: 3 \mathrm{MgO} \cdot \mathrm{B}_{2} \mathrm{O}_{3}$

(a) inner part of $\mathrm{MgO}$-brick

(b) surface layer of $\mathrm{MgO}$-brick

(c) surface layer of the pellet of pure $\mathrm{MgO}$

Fig. 4. X-ray diffraction patterns of MgO-brick and the pellet of pure $\mathrm{MgO}$ treated with vapourof boric oxide for $30 \mathrm{hrs}$, at $1300^{\circ} \mathrm{C}$. 


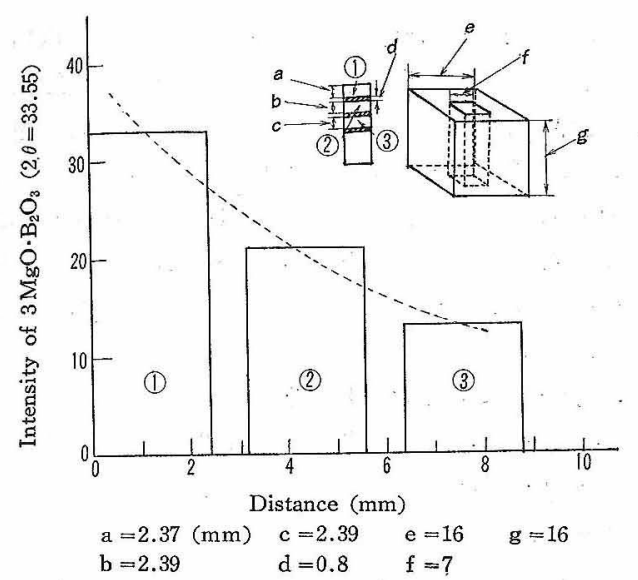

Fig. 5. The changes of the strongest intensity of $\mathrm{X}$-ray of $3 \mathrm{MgO} \cdot \mathrm{B}_{2} \mathrm{O}_{3}$ by distance from surface of $\mathrm{MgO}$-brick treated with vapour of boric oxide for $12 \mathrm{hrs}$, at $1300^{\circ} \mathrm{C}$.

晶の生成が認められる（図-4-a）（ただしこの場合，試 料の垂直な中心線を含んだ $7 \times 7 \times 16 \mathrm{~mm}$ の角柱状の部 分を切り出し, 上面から約 $2.4 \mathrm{~mm}$ ずつの等間隔に横 断載片を切り出して粉砕したものを $\mathrm{X}$ 線粉末法で回折 した，その場合生成鉱物 $3 \mathrm{MgO} \cdot \mathrm{B}_{2} \mathrm{O}_{3}$ 結晶の最強ピー ク $(d=2.67 \AA, h k l: 121)$ を比較すると, 表面の方が 内部にくらべてややピークが強い (図-5)).

一方，20 時閒以上の蒸気侵蝕を受けた試料を冷却し た際，試料表面に肉眼で明らかに異質層とみなし得る剝 離性の白色層を生成しているが，X線回折の結果から， この剝離層の大部分が $\mathrm{MgO} \cdot \mathrm{B}_{2} \mathrm{O}_{3}$ 結晶であることが判 別できる(図-4-b).

また, 特級試薬 $\mathrm{Mg}(\mathrm{OH})_{2}$ を加圧成形して， $1400^{\circ} \mathrm{C}$ で炍焼した $\mathrm{MgO}$ ペレットについて同様な 実験を行な った場合も，硼酸蒸気中で 20 時間以上を保持した試料 表面にほ容易に剝離しやすい層を形成する。この剝離層 の X 線回折図怯棟瓦試料の表面に生成した剝離層中の ものと同じ $\mathrm{MgO} \cdot \mathrm{B}_{2} \mathrm{O}_{3}$ 結晶の回折線を示している（図 $-4-\mathrm{c})$.

3.1.2 $1400^{\circ} \mathrm{C}$ の温度段階における実験結果 いい゙ れの保持時間に扔いても冷却した煉瓦試料中には， $\mathrm{MgO}$ - $\mathrm{B}_{2} \mathrm{O}_{3}$ 結晶の回折線は認められず, $3 \mathrm{MgO} \cdot \mathrm{B}_{2} \mathrm{O}_{3}$ 結晶 の回折線のみが認められる (図-6-b). そして約 20 時 閒を経過したものでは反応の結果生じた液相が試料の下 方へ移動し試料下方にかなり増加し（図一7），約 24 時 間経過後は，増加した液相が試料から下方一滴下した。 この滴下物の冷却したものを X 線回折した結果では， $3 \mathrm{MgO} \cdot \mathrm{B}_{2} \mathrm{O}_{3}$ 結晶の回折線の多が現われている(図-6-a). また, $\mathrm{Mg}(\mathrm{OH})_{2}$ 特級試薬を炍焼した $\mathrm{MgO}$ ペレ ットについて同樣の実験を行なった結果についてる試料 中に新しく生成した化合物としては $3 \mathrm{MgO} \cdot \mathrm{B}_{2} \mathrm{O}_{3}$ 結晶 の回折楾のみが認められる。

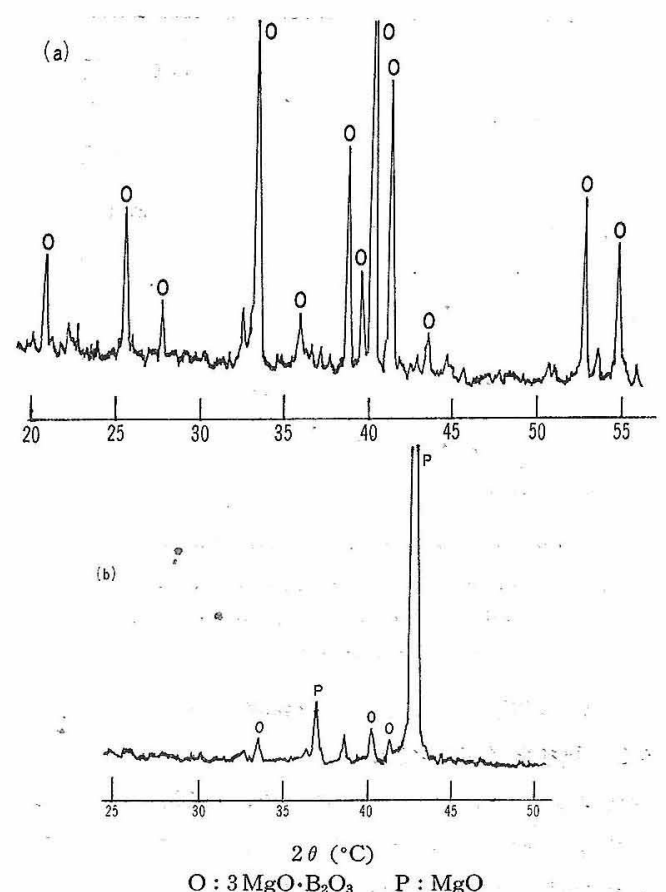

(a) The drop which fell down from $\mathrm{MgO}$-brick

(b) Inner part of $\mathrm{MgO}$-brick

Fig. 6. X-ray diffraction pattern of $\mathrm{MgO}$-brick treated with vapour of boric oxide for $24 \mathrm{hrs}$, at $1400^{\circ} \mathrm{C}$.

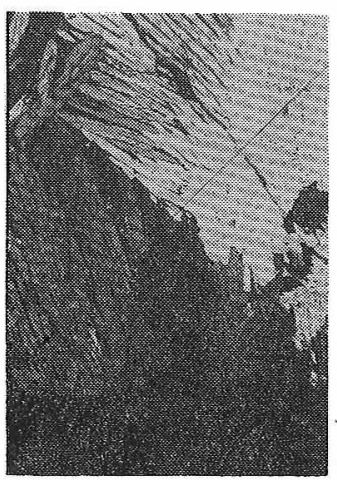

closed nicol

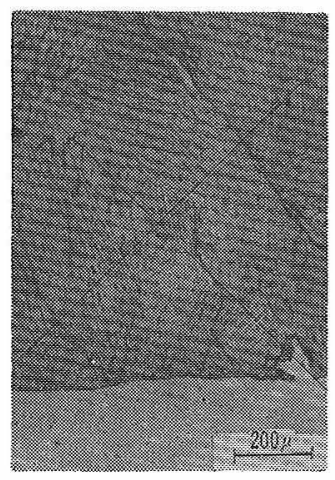

open nicol
Fig. 7. Crystal of magnesium-orthoborate ( $3 \mathrm{MgO}$ $\cdot \mathrm{B}_{2} \mathrm{O}_{3}$ ) deposited in underneath of $\mathrm{MgO}$ brick treated with vapour of boric oxide for $21 \mathrm{hrs}$, at $1400^{\circ} \mathrm{C}$.

\section{2 重量変化}

嗍酸蒸気功煉瓦試料中へ侵入して煉瓦成分と反忘する と，その結果試料の重量増加を引き起す。したがってこ の場合, 試料の重量増加量けほぼ反応生成物の増加量と

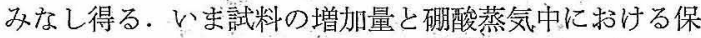
持時間との関係を示せば图-8のようになる。すなわち， $1300^{\circ} \mathrm{C}$ の温度段階では約 20 時間前後を経過した頃加 ら試料の重量増加の保持時閒に対する勾配が大きくなっ ている.これに対して $1400^{\circ} \mathrm{C}$ の温度段階では試料の重 


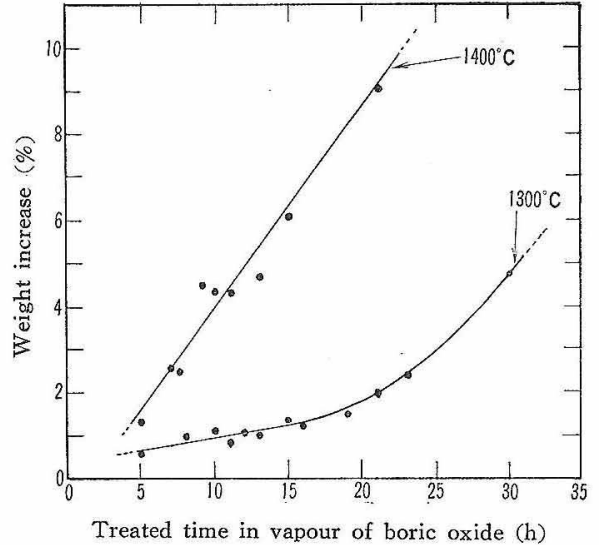

Fig. 8. The changes of weight increase of $\mathrm{MgO}$ brick treated with vapour of boric oxide, at $1300^{\circ} \mathrm{C}$ and $1400^{\circ} \mathrm{C}$.

量は，保持時間に効してほぼ直線的に增加している。

\section{3 見掛気孔率の変化}

硼酸蒸気中における煉瓦試料の保持時間と見掛気孔率 との関係を示せば図-9のようになる。ただし $1300^{\circ} \mathrm{C}$ の温度段階で剥離性の反応層を生じた際には, この剝離

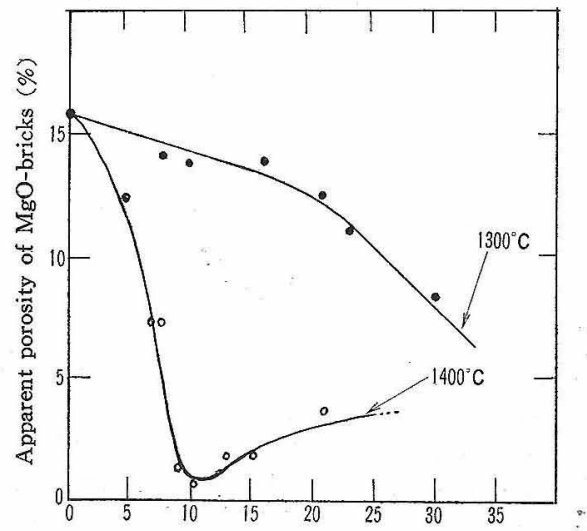

Treated time in vapour of boric oxide $(h)$

Fig. 9. The changes of apperent porosity of $\mathrm{MgO}-$ brick treated with vapour of boric oxide, at $1300^{\circ} \mathrm{C}$ and $1400^{\circ} \mathrm{C}$.

$\therefore$

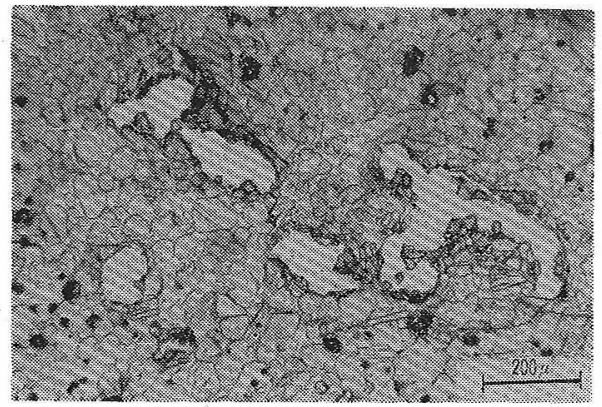

Fig. 10. The microscopic texture of $\mathrm{MgO}$-brick treated with vapour of boric oxide for $10 \mathrm{hrs}$, at $1400^{\circ} \mathrm{C}$
層を取除いた部分を測定した。これによると $1300^{\circ} \mathrm{C}$ の 場合におふいて，20 時間前後を経過した 試料は気孔率が かなり急激に減少している。一方， $1400^{\circ} \mathrm{C}$ の温度段階 において約 10 時間を経過すると0.5\% まで減少するが， 10 時閒以後はやや増加する. そして図-10 の鏡検写真に おいても明らかなように 10 時閒以上を経過した試料内 部は微細な気孔が集まってところどころかなり大きな気 孔を形成している。

\section{4 温度による重量增加の変化}

硼酸蒎気中における試料の保持時 間 50 時間とし て, 加熱温度に対する試 料の重量增加を測定する と，約 $800^{\circ} \mathrm{C}$ 以下では 重量増加が全く認められ ないが， $800^{\circ} \mathrm{C}$ 以上，特 に $1200^{\circ} \mathrm{C}$ 以上の温度に なると極めて急激に試料 の 重量が 増加する(図一 11).

\section{5 試料 中における} ペリクレース結晶の時間 に対する粒径変化

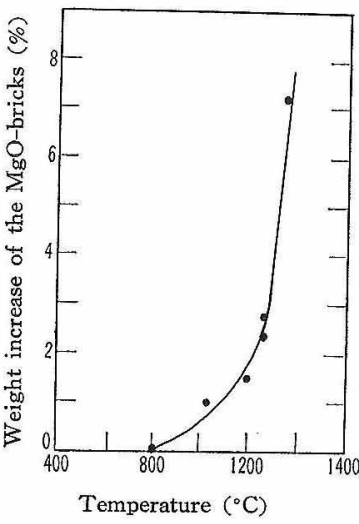

ペリクレース結晶の粒 Fig. 11. The changes of the 径測定は偏光顕微鏡を使 用して試料全体にわた。 てランダムにとった 500 個のペリクレース結晶の weight increase of MgO-brick treated with vapour of boric oxide for $50 \mathrm{hrs}$, in various temperature.

粒径を測定した。ただし，末侵蝕試料及び $1300^{\circ} \mathrm{C}$ 䃆酸 蒸気処理試料は，粒塊部分 (図-1-G 部分) 々結合部分 (図-1-S 部分) とが明膫に区別できるので，それぞれ の部分におけるペリクレース結晶の粒径を測定した。一 方, $1400^{\circ} \mathrm{C}$ 硼酸蒸気処理試料は粒塊部分上 結合部分と の境界が消滅し，試料中におけるほとんざ大部分のペリ クレース結晶粒子が球形に近くなって一様な大きさを持 つ状態を呈するので（図-10 もその一例である），試料 全体にわたるペリクレース結晶の粒径を測定した。

3.5.1 未侵蝕試料 粒塊部分のペリクレース 結晶 は，10 70 $\mu$ にわたる粒径のものがほとんどであり平

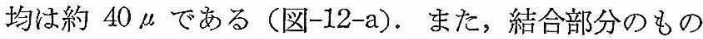

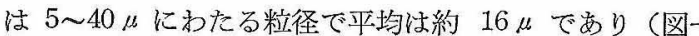
12-a')，粒塊部分と結合部分の各々に存在するペリクレ 一ス結晶粒子の大きさには相当の差が認められる。

3.5.2 $1300^{\circ} \mathrm{C}$ 硼酸蒸気の処理試料 16 時間にわ たる硼酸蒸気の侵蝕を受けた試料中の粒塊部分 ( $\mathrm{G}$ 部 分）におけるペリクレース粓径は（図-12-b)，末侵蝕 試料中における粒径とあまり大差ないが，30 時閒の侵 蝕を受けた 試料中には 80 100 $\mu$ の大きさを 持つペリ クレース䊀子むかなり認められるようになり(図-12-c)， 

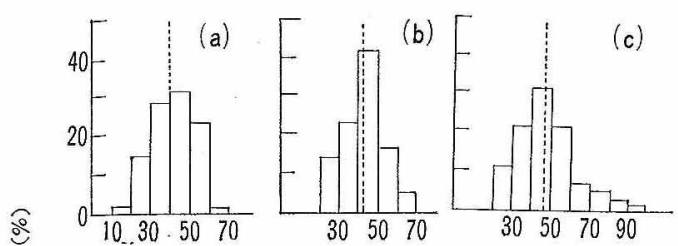

过
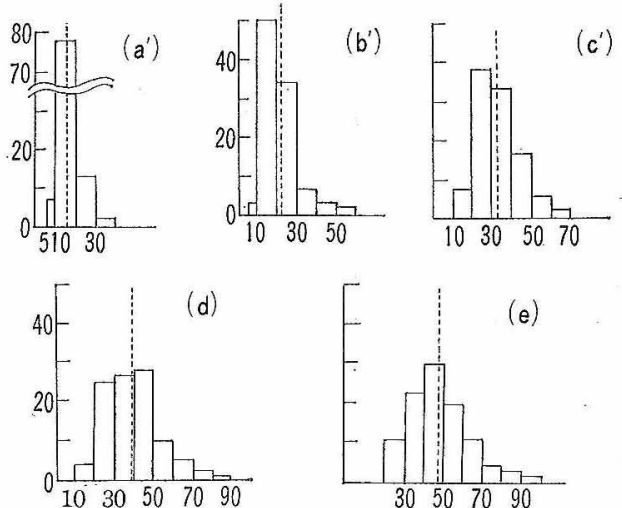

........mean value of the size of periclase crystal

(a) $\sim(c)$ : Periclase in grain $(\mathrm{G})$ of magnesia clinker of $\mathrm{MgO}$-brick

$\left(a^{\prime}\right) \sim\left(c^{\prime}\right)$ : Periclase in bonding part (S) of $\mathrm{MgO}$-brick

(d), (e) : Periclase in the $\mathrm{MgO}$-brick in all portion

(a), (a') : Original MgO-brick

(b), $\left(\mathrm{b}^{\prime}\right): \mathrm{MgO}$-brick treated with $\mathrm{B}_{2} \mathrm{O}_{3}$ vapour for $16 \mathrm{hrs}$, at $1300^{\circ} \mathrm{C}$

(c), (c') : $\mathrm{MgO}$-brick treated with $\mathrm{B}_{2} \mathrm{O}_{3}$ vapour for $30 \mathrm{hrs,}$ at $1300^{\circ} \mathrm{C}$

(d) : $\mathrm{MgO}$-brick treated with $\mathrm{B}_{2} \mathrm{O}_{3}$ vapour for $10 \mathrm{hrs}$, at $1400^{\circ} \mathrm{C}$

(e) : $\mathrm{MgO}$-brick treated with $\mathrm{B}_{2} \mathrm{O}_{3}$ vapour for $21 \mathrm{hrs}$, at $1400^{\circ} \mathrm{C}$

Fig. 12. Distribution of particle size of periclase in $\mathrm{MgO}$-brick treated with vapour of boric oxide at $1300^{\circ} \mathrm{C}$ and $1400^{\circ} \mathrm{C}$.

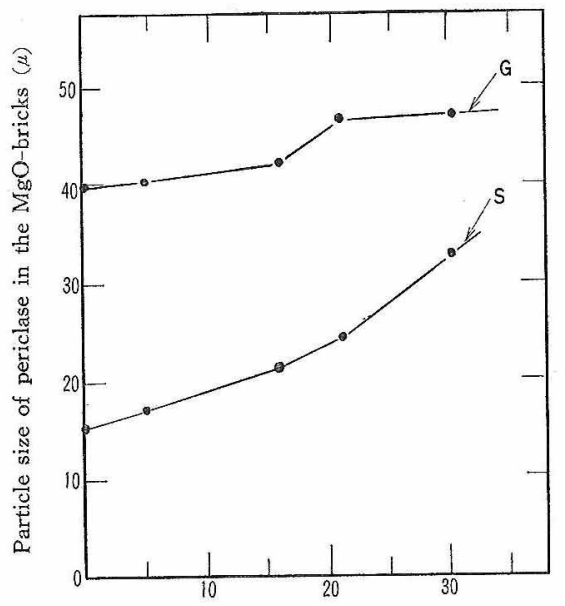

Time of treatment by vapour of boric oxide (h) $\mathrm{G}$ : particle size of periclase in $\mathrm{MgO}$ clinker grain $\mathrm{S}$ : particle size of periclase in bonding part

Fig. 13. The changes of the particle size of periclase in $\mathrm{MgO}$-bricks treated with vapour of boric oxide at $1300^{\circ} \mathrm{C}$.

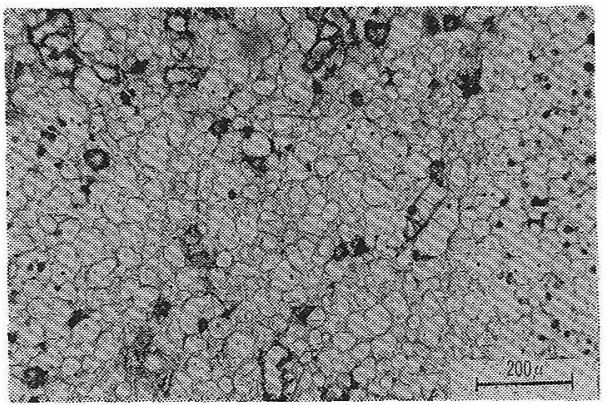

Fig. 14. Microscopic texture of MgO-brick treated with vapour of boric oxide for $30 \mathrm{hrs}$, at $1300^{\circ} \mathrm{C}$.

大きいものは $270 \mu$ に達するよらなものさえ現われて いる．また粒径を則定した 500 個のペリクレース粒子の 平均粓径の時間経過に対する変化を見ると（図-13), 結 合部分 ( $\mathrm{S}$ 部分) に扝けるペリクレース粒子は，粒塊部 分 ( $\mathrm{G}$ 部分) のペリクレース粒子にくらべて大きな粒径 をもつものがかなり急速に多くなり，粒塊部分の平均粮 径が約 20 時間を経過するころからほとんど变化しない のに対し，結合部分に扔ける平均粒径は約 20 時間経過 後に打いてかなり急激に大きくなっている。また，粒塊 部分のペリクレース粒子がほぼ球形をなしているのに対 して，結合部分のペリクレース粒子はやや不規則な外形 をなしているものが多い。しかし 30 時間を経過した武 料では，結合部分のペリクレース粒子は粒塊部分にある ものと同じような球形をとるようになり，平均粒径も粒 塊部分中に打ける平均粒径にほとんど近くなっている結 果，粒塊部分と結合部分との両組織状態を鏡検下で区別 することが困難になっている（図-14）。

\subsection{3 $1400^{\circ} \mathrm{C}$ 硼酸蒸気の処理試料 10 洔閒の硼} 酸蒸気の侵蝕を受けた試料に拉けるペリクレース粒子の 粒径分布範囲は未処理試料のものと比較してあまり違い

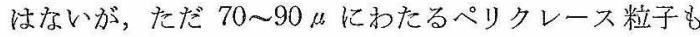
現われるようになって，一般に大きな粒径をむつものが 増加している(図-12-d).さらに 21 時間を経過した試 料では, ペリクレース粒子の平均粒径が增加してほぼ 48 $\mu$ 前後となり 90〜140 子もかなり認められるようになる(図-12-e)、な蛒この 場合 $20 \mu$ 以下の粒径をもつペリクレース粒子はほとん ど認められなくなっている。

\section{4. 考察}

まず実験に使用した嗍酸拉よびその蒸気についての報 告を簡単に挙げてみよう。

Estrada とPendás ${ }^{11}$ とれば， $\mathrm{H}_{3} \mathrm{BO}_{3}$ は $100^{\circ} \sim 200^{\circ} \mathrm{C}$ て $2 \mathrm{H}_{3} \mathrm{BO}_{3} \rightarrow \mathrm{B}_{2} \mathrm{O}_{3}+3 \mathrm{H}_{2} \mathrm{O}$ の脱水反応起して $\mathrm{B}_{2} \mathrm{O}_{3}$ になると報告している. そして高温における硼酸の分子 形態打よび蒸気圧については Speiser, Naiditch 珖よび 
Johnston による研究 ${ }^{2)}$ があって, その中で嗍酸蒸気の分 子形態は $\mathrm{B}_{2} \mathrm{O}_{3}$ または $\mathrm{B}_{4} \mathrm{O}_{6}$ であると報告している.

さらに $\mathrm{MgO}$ と $\mathrm{B}_{2} \mathrm{O}_{3}$ の平衡状態図については Davis および Knight の研究 ${ }^{3}$ があり，それによると $\mathrm{MgO}$ と $\mathrm{B}_{2} \mathrm{O}_{3}$ には $\mathrm{MgO} \cdot \mathrm{B}_{2} \mathrm{O}_{3}, 2 \mathrm{MgO} \cdot \mathrm{B}_{2} \mathrm{O}_{3}$ および $3 \mathrm{MgO}$. $\mathrm{B}_{2} \mathrm{O}_{3}$ の各化合物があることや，それらの性質等を報告 している。その報文中にあげられている $\mathrm{MgO}-\mathrm{B}_{2} \mathrm{O}_{3}$ 系 の平衡状態図を示せば図-15のようである.

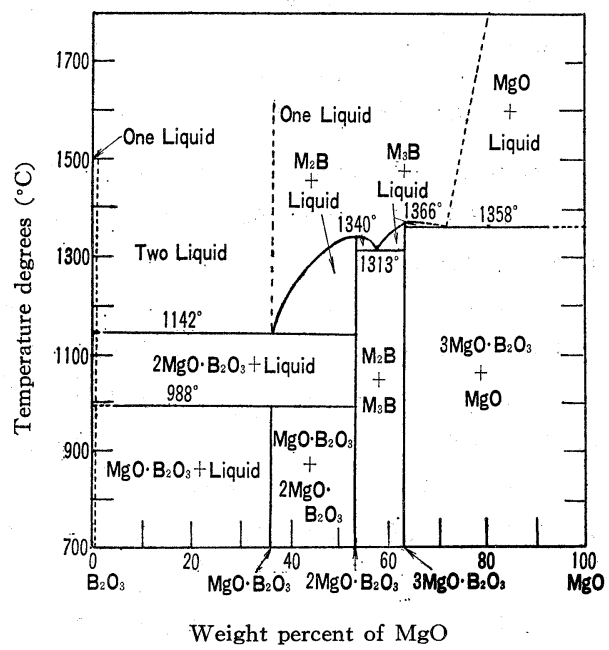

Fig. 15. The system of magnesium oxide-boric oxide. (by H.M. Davis and M.A. Knight)

まず $1300^{\circ} \mathrm{C}$ の温度段階における実験では. 約 20 時 間以内の硼酸蒸気処理で $3 \mathrm{MgO} \cdot \mathrm{B}_{2} \mathrm{O}_{3}$ 結晶の生成が試 料全体にわたって認められ（図-4-a)，これ以上の処理 時間を経過した試料は，冷却時にその表面に易離性に富 んだ白色の異質層を形成する。これは $\mathrm{X}$ 線回折の結果 (図-4-b) によればマグネシウムメタ嗍酸 $\left(\mathrm{MgO} \cdot \mathrm{B}_{2} \mathrm{O}_{3}\right)$ の結晶を含有したものであって, このような現象は純粋 な $\mathrm{MgO}$ で行なった実験, すなわち同じ温度, 時間条件 で硼酸蒸気に侵蝕させる場合にも起っている.すなわち 純粋な $\mathrm{MgO}$ を 30 時間硼酸蒸気で処理した場合, そ の表面に生成した剝離性の異質層を X 線回折した結果 （図-4-c）によれば，やはり同じマグネシウムメ夕嗍酸 $\left(\mathrm{MgO} \cdot \mathrm{B}_{2} \mathrm{O}_{3}\right)$ の結晶存在が確認される.したがって上 述した煉瓦試料の表面にマグネシウムメタ硼酸の結晶を 生成するのは煉瓦中に含有されている不純物の影響によ るものではないと考えられる。

一方， $1400^{\circ} \mathrm{C}$ の温度段階にお污実験で，煉瓦試料 および純粋 $\mathrm{MgO}$ 試料中に新しく生成している化合物 はマグネシウムオルソ硼酸 $\left(3 \mathrm{MgO} \cdot \mathrm{B}_{2} \mathrm{O}_{3}\right)$ 結晶であっ てマグネシウムメタ硼酸 $\left(\mathrm{MgO} \cdot \mathrm{B}_{2} \mathrm{O}_{3}\right)$ 結晶に相当する 回折線は全く認められなかったが，これらの実験結果を 一応化学式で表わせば,

$1300^{\circ} \mathrm{C}$ の温度段階において,

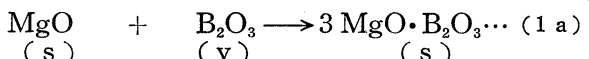

$$
\begin{aligned}
& 3 \mathrm{MgO} \cdot \mathrm{B}_{2} \mathrm{O}_{3}+\mathrm{B}_{2} \mathrm{O}_{3} \longrightarrow 2 \mathrm{MgO} \cdot \mathrm{B}_{2} \mathrm{O}_{3} \cdots(1 \mathrm{~b}) \\
& \text { ( } \mathrm{s})^{2}(\mathrm{v}) \text { ( } \\
& \underset{(\mathrm{s})}{\mathrm{MgO}} \mathrm{B}_{2} \mathrm{O}_{3}+\underset{(\mathrm{v})}{\mathrm{B}_{2} \mathrm{O}_{3}} \rightarrow \underset{(\mathrm{l})}{\mathrm{MgO} \cdot \mathrm{B}_{2} \mathrm{O}_{3}} \cdots(1 \mathrm{c})
\end{aligned}
$$

また， $1400^{\circ} \mathrm{C}$ の温度段階において，

$$
\underset{(\mathrm{s})}{\mathrm{MgO}}+\underset{(\mathrm{v})}{\mathrm{B}_{2} \mathrm{O}_{3}} \longrightarrow \underset{(\mathrm{l})}{\mathrm{MgO}} \cdot \mathrm{B}_{2} \mathrm{O}_{3}
$$

(ただし $\mathrm{s}:$ solid, $\mathrm{v}:$ vapour, $1:$ liquid)

となる。

したがっていま $1300^{\circ} \mathrm{C}$ では(1)の反応が起り $1400^{\circ} \mathrm{C}$ では(2)の反応が起る理由を考察してみよう．まず (1 a ) と (2) の反応の大きな相違点は, 反応生成物の $3 \mathrm{MgO}$. $\mathrm{B}_{2} \mathrm{O}_{3}$ が固相 (結晶) であるか液相であるかという相違 である。すなわち (1 a ) の場合その生成物が固相である ために，このマグネシウムオルソ硼酸が $\mathrm{B}_{2} \mathrm{O}_{3}$ 蒸気によ って次の反応段階である $(1 \mathrm{~b})$ を経て最後の反応段階で ある (1 c) まで進むが, (2)の場合には生成物が $3 \mathrm{MgO}$ • $\mathrm{B}_{2} \mathrm{O}_{3}$ の組成をもつ液相であるために，これと $\mathrm{B}_{2} \mathrm{O}_{3}$ 蒸気が (1 b ) および (1 c ) に示されるよらな反応をほと んど起さず， $\mathrm{MgO}$ が消費し尽されるまでこの反応がか なり急激に起り続けるものと考えられる.

いまこの煉瓦試料を使用した侵蝕実験の結果が不純物 の極微量の特級試薬から製作した $\mathrm{MgO}$ ペレットで行な った侵蝕実験結果とほとんど同じである結果（3.1 参 照) を考えて, Davis および Knight による平衡状態 図を参照しながら，上述した反応過程を考えてみよう。

まず $1300^{\circ} \mathrm{C}$ における侵蝕では，煉瓦試料中へ $\mathrm{B}_{2} \mathrm{O}_{3}$ 蒸気が侵入して (1 a) の反応が起り, その結果固相のマ グネシウムオルソ硼酸の結晶を生成する. この場合試料 の表面やあるいは表面に近い試料内部ほど容易に $\mathrm{B}_{2} \mathrm{O}_{3}$ 蒸気が作用するので，これらの部分にマグネシウムオル ソ嗍酸 $\left(3 \mathrm{MgO} \cdot \mathrm{B}_{2} \mathrm{O}_{3}\right)$ の結晶を多量に生成するが (図5), 煉瓦試料中に侵入して, その部分の $\mathrm{MgO}$ と反応 する $\mathrm{B}_{2} \mathrm{O}_{3}$ の量が $\mathrm{MgO}-\mathrm{B}_{2} \mathrm{O}_{3}$ 系でほぼ 0 36.5\% (重 量）の間は，(1 a)，の反応が起り続ける. しかし $\mathrm{B}_{2} \mathrm{O}_{3}$ 蒸気の接触侵入が最も多い試料表面において表面近くに ある $\mathrm{MgO}$ と反応する $\mathrm{B}_{2} \mathrm{O}_{3}$ 蒸気の量が, $\mathrm{MgO}-\mathrm{B}_{2} \mathrm{O}_{3}$ 系で約 $36.5 \%$ (重量) 以上に達していると， $\mathrm{B}_{2} \mathrm{O}_{3}$ 蒸 気は, 生成しているマグネシウムオルソ硼酸 $(3 \mathrm{MgO}$ $\left.\cdot \mathrm{B}_{2} \mathrm{O}_{3}\right)$ の結晶とさらに急激に反応する結果 $(1 \mathrm{~b})$ を経 て (1 c c) で示される反応過程をとり, 最終的には $\mathrm{MgO}$ - $\mathrm{B}_{2} \mathrm{O}_{3}$ の組成に近似した融液を形成するに至る. その結 果, 煉瓦試料が冷却された場合の試料表面にはマグネシ ウムメタ嗍酸 $\left(\mathrm{MgO} \cdot \mathrm{B}_{2} \mathrm{O}_{3}\right)$ の結晶が析出するものと考 光られる。

次に， $1400^{\circ} \mathrm{C}$ の温度段階における反応の場合には, 
試料全体のペリクレース粒子 $(\mathrm{MgO})$ と活発に反応する $\mathrm{B}_{2} \mathrm{O}_{3}$ 蒸気は $\mathrm{MgO}-\mathrm{B}_{2} \mathrm{O}_{3}$ 系で $36.5 \% \mathrm{~B}_{2} \mathrm{O}_{3}$ (重量) 以上 のいずれの混合量においてもペリクレース粒子 $(\mathrm{MgO})$ と反応して常に液相を形成している. しかし X 線回折 の結果, 冷却した試料中にマグネシウムオルソ硼酸 (3 $\mathrm{MgO} \cdot \mathrm{B}_{2} \mathrm{O}_{3}$ ) の結晶生成物以外の 回折線が 認められな いことは, ペリクレース $(\mathrm{MgO})$ 結晶と反応する際の $\mathrm{B}_{2} \mathrm{O}_{3}$ 蒸気量が, $\mathrm{MgO}-\mathrm{B}_{2} \mathrm{O}_{3}$ 系でほぼ $43.3 \%$ を越えな いことを示している*. これは試料中の各ペリクレース 結晶周縁に形成された $\mathrm{MgO}-\mathrm{B}_{2} \mathrm{O}_{3}$ 融液薄膜中で, ペリ クレース結晶の熔解と $\mathrm{B}_{2} \mathrm{O}_{3}$ 蒸気の侵入とが連続的に継 続しているために, 試料の冷却時においてマグネシウム オルソ嘲酸 $\left(3 \mathrm{MgO} \cdot \mathrm{B}_{2} \mathrm{O}_{3}\right)$ の結晶を析出するような組 成比を持つ融液条件が常に保たれているからであると考 えられる。

上述したように，一般に試料を硼酸蒸気中に保持する と， $1300^{\circ} \mathrm{C}$ あるいは $1400^{\circ} \mathrm{C}$ で(1)あるいは(2)の反応が 起り試料に対する硼酸蒸気の付着量を無視すれば**反応 生成物のみが試料の重量増加をもたらすことになり，し たがって同一温度では試料重量の増加量が直接硼酸蒸気 による侵蝕量の程度を表わすと考えることができる．

いま硼酸蒸気中での試料の保持時間に対する試料の重 量増加の関係を図示したもの（図-8）を見ると， $1300^{\circ} \mathrm{C}$ の温度段階において，20 時間前後を経過した試料の重 量増加は急に増大し始めているが，この時期は $\mathrm{MgO}$. $\mathrm{B}_{2} \mathrm{O}_{3}$ に相当する組成の融液が 表面に生成する時期とほ ぼ一致している.したがって 20 時間経過後の急勾配は (1 a) の反応からさらに (1 b) と (1 c ) の反応が継続し て起り始めた結果であろらと考えられる.

一方, $1400^{\circ} \mathrm{C}$ の温度段階における実験で, 25 時間以 内に保持された試料中では, (2)の反応のみが進行する結 果, 重量増加の時間に対する勾配はほぼ直線的となって いる.

次に温度による侵蝕量の変化を考える. 一般に温度に よって起る反応は各温度段階で内容的に異なっている場 合が多いけれども，一応侵蝕の度合を計る目安として， 試料の重量増加を考えると（図-11), $800^{\circ} \mathrm{C}$ 以下では硼 酸蒸気はほとんど試料と反応を起さず, $800^{\circ} \mathrm{C}$ 以上, 特 に $1200^{\circ} \mathrm{C}$ 以上から相当急激に反応を起しており, 温度 による影響は極めて大きいものであると考えられる.

さらに試料中におけるペリクレース結晶の粒径変化を みると（図-12), 硼酸蒸気中に棟瓦試料を保持した時間

* X線回折にかからない゙く少量のメタ硼酸塩が存在してい るかどうかは今のところ明確にすることが出来ないが，た とえ存在してもごく少量であると一応仮定して反応にあず かる $\mathrm{B}_{2} \mathrm{O}_{3}$ 量它「宝底 $43.3 \%$ を越えない」ものとした。

** 硼酸蒸気と反応しない白金板を同じように実験しても重量 増加は全くなく, また硼酸とほとんど反応しないジルコン 棟瓦にその蒸気をあてても重量増加がほとえどないことか らも硼酸蒸気の附着量は無視できよう.
が経過するにしたがってペリクレース粒子は一般に大き くなるが，これは大小の粒子が混合，隣接している際 に，小粒相互あるいは小粒子と大粒子が聚合して大きく なるものと考えられ, $1300^{\circ} \mathrm{C}$ の温度段階では, 試料内 部に液相を生成しないために，ペリクレース粒子相互の 接触が長く保たれていて粒子の聚合と成長が絶えず進行 する結果, 30 時間を経過した試料中には, $270 \mu$ 前後の 巨大な結晶粒子も少量ながら認められるようになる。こ れに対して， $1400^{\circ} \mathrm{C}$ の温度段階の試料においては，21 時間で $140 \mu$ 程度の結晶粒子がごく少量は認められる が，試料内部ではこの時間経過までにかなりの液相が生 成して, ペリクレース粒子相互の直接な接触を妨げられ るため，21。時間以上に時間が経過してもそれ以上の結 晶粒子の成長はほとんどないものと考えられる.

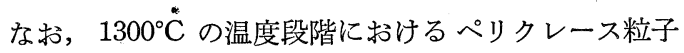
の平均粒径の変化 (図-13) において，20 時間前後の蒸 気侵蝕で, 粒塊部分中におけるペリクレース粒子が急速 に成長し，20 時間以上の時間経過ではほとんど変化が 認められないのに対し, 結合部分におけるペリクレース 粒子は， 20 時間前後から一層成長が急激になる.これ は結合部分におけるペリクレース粒子が粒塊部分におけ るものに比較して小粒である結果, この部分のペリクレ 一ス粒子の聚合と成長が一層促進されるものと考えられ る.そして，この部分のペリクレース粒子が，急速に成 長するにしたがって, 試料の開口気孔が塞がれて見掛気 孔率の変化（図-9）もこれに相応した低下の状態を示す ようになるものと考えられる. そして，試料の気孔率低 下により,硼酸蒸気の内部侵入が少なくなるにつれて,棟 瓦試料の表面においては, 最初の生成物である $3 \mathrm{MgO}$. $\mathrm{B}_{2} \mathrm{O}_{3}$ 結晶と硼酸蒸気との反忘がさらに進み，ついには $\mathrm{MgO} \cdot \mathrm{B}_{2} \mathrm{O}_{3}$ の液相が，新しく生成し始めるものと考え られる。

次に見掛気孔率の変化 (図-9) を見ると, $1300^{\circ} \mathrm{C}$ の 温度段階で蒸気侵蝕時間が 20 時間を 経過するころから 見掛気孔率が急激に低下している。これは $\mathrm{MgO} \cdot \mathrm{B}_{2} \mathrm{O}_{3}$ の組成をもつ反応物が液相となって試料表面に生成し始 める時間とほぼ一致している.つまり液相の生成によっ て, 試料表面に開口していた気孔が塞がれて密閉気孔と なり，その結果この試料の見掛気孔率が急速に減少し始 めたものと考えられる。

また, $1400^{\circ} \mathrm{C}$ の温度段階の場合に, 10 時間を経過し た試料の見掛気孔率は $0.5 \%$ まで減少するが，10 時間 以後にやや増加している. この過程を内容的に考える と, 初めの 10 時間前後までは試料の表面や内部にほぼ $3 \mathrm{MgO} \cdot \mathrm{B}_{2} \mathrm{O}_{3}$ の組成をもつ液相を生成する結果，ます 試料中の開口気孔が塞がれて密閉気孔となり, そのため に試料の見掛気孔率を急激に減少させるが，10 時間前 後を経過した以後には生成した液相が試料の下方へ流動 
し始めて棟瓦試料中の開口気孔が再びやや増加し，その ために見掛気孔率が少し増加したものと考光られる。

\section{5. 総括}

（1）嗍酸蒸気がマグネシア煉瓦に接触した場合に起 る特有な侵蝕機構は硯酸蒸気が煉瓦中の主要鉱物である ペリクレース結晶とかなり急速に反応して，終局的には 低融点のマグネシウム硼酸塩や，その化合物組成に近似 した液相を形成して票気侵蝕が進行していくものと考え られる。

（2）その場合， $\mathrm{B}_{2} \mathrm{O}_{3}$ 蒸気とペリクレース $(\mathrm{MgO})$ 結晶の反応を一応化学式で表わせば,

$1300^{\circ} \mathrm{C}$ の場合は

$$
\begin{aligned}
& \mathrm{MgO}+\mathrm{B}_{2} \mathrm{O}_{3} \rightarrow 3 \mathrm{MgO} \cdot \mathrm{B}_{2} \mathrm{O}_{3} \\
& \text { ( } \mathrm{s}) \quad(\mathrm{v}) \quad(\mathrm{s}) \\
& 2 \mathrm{MgO} \cdot \mathrm{B}_{2} \mathrm{O}_{3}+\mathrm{B}_{2} \mathrm{O}_{3} \rightarrow 2 \mathrm{MgO} \cdot \mathrm{B}_{2} \mathrm{O}_{3} \\
& \text { ( } \mathrm{s}) \quad(\mathrm{v}) \quad(\mathrm{s}) \\
& 2 \mathrm{MgO} \cdot \mathrm{B}_{2} \mathrm{O}_{3}+\mathrm{B}_{2} \mathrm{O}_{3} \rightarrow \mathrm{MgO} \cdot \mathrm{B}_{2} \mathrm{O}_{3} \\
& \text { (s) (v) (1) } \\
& \text { (s : solid, vapour, } 1: \text { liquid) }
\end{aligned}
$$

となり，まず(1 a ) の反応が起り，煉瓦全体にわたっ て，マグネシウムオルソ硼酸 $\left(3 \mathrm{MgO} \cdot \mathrm{B}_{2} \mathrm{O}_{3}\right)$ 結晶を生 成し, 次に生成した $3 \mathrm{MgO} \cdot \mathrm{B}_{2} \mathrm{O}_{3}$ 結晶に嗍酸蒸気が作用 して，ほぼマグネシウムメタ硼酸 $\left(\mathrm{MgO} \cdot \mathrm{B}_{2} \mathrm{O}_{3}\right)$ に相当 する液相を棟瓦表面に生成しながら侵蝕が進んでいく。

また $1400^{\circ} \mathrm{C}$ の場合には，

$\mathrm{MgO}+\mathrm{B}_{2} \mathrm{O}_{3} \rightarrow 3 \mathrm{MgO} \cdot \mathrm{B}_{2} \mathrm{O}_{3}$
( $\mathrm{s}$ )
( v)
(1)

となり，全体にわたって，ほぼマグネシウムオルソ嗍酸 $\left(3 \mathrm{MgO} \cdot \mathrm{B}_{2} \mathrm{O}_{3}\right)$ に相当する組成の液相を形成し，それが 煉瓦下方に流下しながら侵蝕が進んでいく。

（3）硼酸蒸気とマグネシア煉瓦の反応は， $800^{\circ} \mathrm{C}$ 以 上，特に $1200^{\circ} \mathrm{C}$ 以上の温度で急速に進行する.これに 対して， $800^{\circ} \mathrm{C}$ 以下の温度では，ほとんど両者の反応が 認められない。

（4）マグネシア煉瓦中のペリクレース粒子は硼酸蒸 気で煉瓦を侵蝕する時間が長くなるにしたがって大きく なっていくが，その成長速度は，粒塊部分に括ける粒子 よりも結合部分に扔ける粒子の方が大きい.

$$
\text { あと がき }
$$

なお，この報文においては，硼酸蒸気がマグネシフ煉瓦を侵 蝕する際の時間及び温度に対する变化を，反応生成物の種類や マグネシア結晶粒径の変化，あるいはまた反忘による試料の重 量変化および 見掛気孔率の変化等によって追求したが，それら の際に打ける内部組織の变化や反応物の生成状態などを微視的 な観点から詳しく解明するに到らず，ことに原料中に含まれて いる不純物（フォルステライト，その他）功侵蝕に捺いて果す 役割を追求することが出来なかった。こ机は次報において報告 するであうう。

\section{文献}

1) D. Alvarez-Estrada \& S. de Azu Pendás Ber. Deut. Keram. Ges. 43, 16-18 (1966).

2) Rudolph Speiser, Sam Naiditch \& Herrick L. Johnston J. Am. Chem. Soc. 72, 2578-2580 (1950).

3) H.M. Davis \& M.A. Knight J. Am. Ceram. Soc. 28 [4] 97-102 (1945).

(6/23/1967 受付)

\title{
MO- $\mathrm{P}_{2} \mathrm{O}_{5}$ 系ガラスの赤外線吸収スペクトル とその物性におよぼす残留水分の影響
}

\section{成 瀬 省・阿部良弘・井上博義}

(名古屋工業大学)

\section{Infra-red Spectra and Some Physical Properties of Divalent Metal Phosphate Glasses Containing Residual Water}

By

Akira NARUSE, Yoshihiro ABE and Hiroyoshi INOUE

(Nagoya Insitute of Technology)

\begin{abstract}
Notwithstanding water content of phosphate glass is, in general, exceedingly greater than that of silicate or borate glass, it is rather difficult to gather informations about influences of water on structure and properties of glass.

First, in purpose to study on this problem more thoroughly, the writers prepared a vast number of glass samples having the different values of $\mathrm{MO} / \mathrm{P}_{2} \mathrm{O}_{5}$ ratio, $R_{\mathrm{M}}$, or (MO $\left.+\mathrm{H}_{2} \mathrm{O}\right) / \mathrm{P}_{2} \mathrm{O}_{5}$ ratio, $R_{\mathrm{MH}}$. Water content of glass was regulated by means of repeated
\end{abstract}

